$M r$. Hanke is the man primarily responsible for developing the $F H A$ 's land use intensity system, a system designed to make FHA financing available for planned units and permit a significant change in the character of land development. The author believes change is essential, because the existing legal and financial restrictions are for the most part founded upon assumptions that are no longer realistic. In this article, Mr. Hanke explains in considerable detail the mechanics of the land use intensity scale. In addition he discusses its potential, already partially realized, for implementing local zoning regulations in order to provide a sound statutory basis for planned unit developments.

\title{
PLANNED UNIT DEVELOPMENT AND LAND USE INTENSITY
}

\section{BrroN R. HANKE $\dagger$}

Zoning in its first half century has been a mixed blessing. Properly administered, it has helped to execute long range city plans and to conserve the usefulness of urban properties. On the other hand, zoning has usually pressed new residential development into stereotyped molds which are shaped by the concept of lot by lot development. The result is the widely decried monotony of most urban development and its lack of adequate open spaces for livability and recreation.

Instead of encouraging the best use of land, zoning and other planning regulations too often have blocked new planning concepts designed to meet modern needs. More than thirty years ago Radburn, New Jersey showed how man and automobile both gain from a superblock planned with a central park, a peripheral collector street and quiet safe residential lanes between; see Figures 1 and 2. Despite the success of Radburn, even now, local regulations rarely encourage developers to use the superblock concept and other innovations promising a better urban environment.

The shortcomings in new residential areas derive largely from regulatory methods which no longer meet the needs of modern life or fit the current scale of industry. The usual approach to zoning and

$\dagger$ Chief Land Planner, Federal Housing Administration. Director, Homes Association Study for the Urban Land Institute. Co-author, The Homes Association Handbook.

Mr. Hanke holds graduate degrees in city planning and landscape architecture from Harvard University. 
subdivision regulations has been lot by lot development with street frontage required for every lot and with density controlled by lot size. Unfortunately this emphasizes lot count instead of livability as a design objective. Since parks and other common open spaces reduce the total lot count, they are seldom provided.

The rapid changes of our industrial society have outmoded this lot by lot approach. The large scale of merchant homebuilding operations, for example, was not foreseen at the inception of comprehensive zoning in 1926. Its prevalence even now scarcely recognized in most current zoning regulations. Similarly, most residential zoning remains unadjusted today to the new ways of living inherent in our greater leisure and new recreation patterns. It seldom recognizes fully the new kinds of living environment possible now through home air conditioning and many other technological advances of recent decades.

Until recently, the Federal Housing Administration (FHA) has had this same technical lag in its standards and procedures. ${ }^{1}$ In the land subdivisions of the forties and fifties, to be sure, FHA led the shift from the nonfunctional gridiron street system to the curvilinear street system adapted to traffic and topography. But basically FHA too has been following the lot by lot concept so common in local planning and zoning regulations.

\section{The Change From Building Lot to Development Unit}

A better approach started to evolve with large scale home building programs executed in World War II. FHA's firm commitmenta for private housing projects for war workers challenged homebuilders to develop large scale operations and fostered the forerunners of today's merchant homebuilders. The pre-war craft of custom building house by house to a definite sales order was transformed into a building industry producing in volume for a market. By 1958 approximately six out of every seven new homes were being built for sale on the general market rather than to the advance order of individuals. ${ }^{2}$ By 1964 more than half the new homes were constructed by builders who build over one hundred homes a year; nineteen out of twenty were

1 New housing construction financed with FHA insured private mortgages are subject to FHA technical standards as well as local public regulations. Ranging over the past decade from 13 to $23 \%$ of the total, FHA's participation influences but does not dictate the standards of all housing construction. The FHA standards and procedures are in FHA, Minimum Property Standards for ONe and Two Living UNITS No. 300 (rev. ed. 1960); FHA, Minimum Property Standards FOR MultiFamiry Housing No. 2600 (1963); 7 FHA Manual, Underwriting Procedures (1959), and each local FHA Insuring Office has its own set of Neighborhood Standards.

2 Johnson, Technological Changes in Residential Construction 1961-1970, in 4 Staff of Subcomsmittee on Housing, Senate Comm. on Banking and Currency, Study of Mortgage Credit 130-42 (Comm. Print 1958). 
constructed by builders who build more than ten homes a year. The typical builder was working in a subdivision of 192 lots. $^{3}$ With home building and land development at this scale, the simple and obvious approach is to look at a housing development in its totality as a living environment rather than concentrating on each lot individually.

The concept of a development as a unit in itself is most readily accepted when it is proposed in the form of a new community or neighborhood unit complete with its own school, park and shopping center. It was in such very large scale proposals, that the local planning agency first joined the developer in a broad view of an entire planned unit. Notable among early efforts was the 1949 adoption of a planned community zone by Prince George's County, Maryland and the subsequent creation of two complete communities with varied building types, open spaces, schools, shopping centers and other community facilities. ${ }^{4}$ In Prince George's County requirements for the special zone include a minimum size of about 500 families and a maximum density of eight families per gross acre. St. Louis County, Missouri, Pittsburgh, Pennsylvania, Fremont, California and others followed suit with modified approaches. Special exceptions or variances were used instead of a special zone in other localities. ${ }^{5}$

Regardless of the procedural devices used, these efforts to adjust zoning to the new community or neighborhood unit recognized the need to control urban growth development unit by development unit instead of lot by lot. However, gearing these approaches to a complete community unit severely limited their usefulness. The search for planning flexibility for development units of a smaller size then led logically to density zoning.

\section{New Approaches and Some New Questions}

Density zoning dispenses with lot size as the key control. Instead it relies upon a maximum number of living units per acre, applied to the development unit as a whole. No longer hobbled by lot size limitations, the developer's planner arranges the fixed number of living units on the land to obtain the best land use. He designs the best

3 Rogg, Sumichrast \& Farguhar, The 1964 NAHB BuIlder Member Survegy (National Association of Homebuilders 1964).

4 Tuemmler, Zoning for the Planned Community, Urban Land, April, 1954, p. 3, reprinted in Urban Land Institute, Tech. Bull. 42, App. A, at 24 (1961).

5 Support for these efforts came in February 1952 from the federal government. Its Suggested Land Subdivision Regulations included a specific variance permitting a local planning commission to modify subdivision standards and requirements for a large scale development such as a new town, complete community or a neighborhood unit. Housing \& Home Finance Agency, Suggested Land Subdivision RegulaTIONS (rev. ed. 1960).

6 Lovelace \& Weismantei, Density Zoning: Organic Zoning for Planned Residentral Developments (Urban Land Institute Tech. Bull. 42, 1961). 
possible environment for living on that site, considering occupant desires, market demand, land features, maintenance needs, and costs of construction and maintenance. This freedom of detail design within a maximum density opens exciting possibilities for variety and improvement in new residential development.

The cluster subdivision of detached homes amid preserved open spaces is one example with a widespread potential. Radburn, New Jersey, in Figures 1 and 2, employs this technique in the superblock pattern, with areas of rowhouses and apartments as well as detached homes. Another example is the townhouse development featuring landscaped malls and recreation facilities. This is illustrated by the individually owned one story townhouses of Hartshorn, Richmond, Virginia, in Figure 3, and the two story townhouses of Pomeroy Green in Santa Clara, California, in Figure 4.

The FHA suggests a variety of other possibilities of improved living environment in its Land Planning Bulletin 6, Planned-unit Development With a Homes Association. ${ }^{7}$ Design possibilities are explored in depth in two recent technical bulletins ${ }^{8}$ of the Urban Land Institute (ULI).

Despite their promise of better urban development, these concepts have not been without difficulties in practical application. In answering these difficulties, the FHA has focused on the three areas to be discussed here. These are the questions of planning standards, the maintenance of common areas, and the time stages in the development process.

\section{Planned Unit Development}

As discussed here and presented in FHA's Bulletin 6, a planned unit development is a residential land subdivision of individually owned homes with neighborhood owned open areas and recreation facilities. It is a relatively new approach to a time proven concept of residential land use. Basically, it incorporates a variation of the "village square" idea.

In the cluster technique for developing new residential areas, large open spaces and recreational areas are obtained by intensive use of land for housing in some sectors while preserving other sectors as open

7 FHA, Planned-unit Development With a Homes Assoctatron (Land Planning Bull. î́o. 6, rev. ed. 1964).

8 Urban Land Institute \& National Ass'N of Home Builders, New AppRoaches to Residential land DeveropMent: A Study of Concepts and InNovatrons (Tech. Bull. 40, 1961) ; URBan LaNd Institute \& National Ass'N of Home Butiders, Innovations and Traditions in Community Development: A Comparative Study of Resmential Land Use (Tech. Bull. 47, 1964). 
space for the benefit of the residents. This does not necessarily alter overall density. It does permit pooling part of the land for the greater benefit of all concerned.

The cluster subdivision and other types of planned unit development benefit the home buyer in several ways: (1) lower priced homes achieved by cost savings through more efficient land planning with shorter networks of utilities and pavements; (2) small private yards for outdoor living with a minimum of maintenance chores and a maximum of time for recreation and other activities; (3) large common areas of green open spaces for an attractive neighborhood setting maintained by efficient, experienced management; and (4) a neighborhood recreation center for swimming, crafts, meetings, and other group activities, at nominal expense through shared costs.

The common property in a planned unit development is a parcel or parcels of land, together with the improvements thereon, the use and enjoyment of which are shared by the owners and occupants of the individual building sites. The ownership of the common property may be either public or private.

\section{A Homes Association To Maintain the Common Areas}

Public ownership and maintenance of common properties appears to be the simplest approach, and in fact it does eliminate some problems. In many cases, however, public maintenance of common property other than streets and the more usual utilities is not available. Moreover, for some types of development layout, it may not be in the best interests of the home owners, the development, the municipality, or the county. For example, it is unreasonable to expect a public agency to maintain a common area which is largely enclosed by the homes it serves and, therefore, virtually unavailable to the general public. On the other hand, public maintenance of common properties that are readily accessible to the general public may encourage heavy public use which can adversely affect the residents of the subdivision. This would undercut one of the principal attractions of the planned unit concept. Fortunately, satisfactory maintenance and operation of common properties are possible through a private, automatic membership homes association, in other words a property owners association. The public interest in the privately owned common open area may be protected by an open space easement to the local public authority.

A homes association is an incorporated, nonprofit organization operating under recorded land agreements through which (a) each lot owner in a described land area is automatically a member, and (b) each 
lot is automatically subject to a charge for a proportionate share of the expenses of the homes association's activities, such as common property maintenance.

Homes associations for the maintenance of common properties under agreements running with the land can be traced conceptually as far back as medieval England. Pioneered decades ago in modern form, several hundred such associations with memberships embracing over one hundred thousand homes now exist in the United States.

A comprehensive study of the experiences of these associations was recently completed by the Urban Land Institute (ULI) under a research contract with the FHA. The study reports the satisfaction of the residents and others with the common properties, and the effect of the common properties on the value and marketability of the homes. The incidence of resident satisfaction and favorable market effect is extremely high. Problems are relatively few, and even for these problems solutions are available. The study findings are published in ULI's Technical Bulletin 50, The Homes Association Handbook. ${ }^{9}$ The extensive report includes a narrative excursion through numerous existing association developments of various kinds. It presents detailed guidelines for the planning, creation and operation of new developments, including legal principles and model forms.

\section{The Size of the Planned Unit}

A focus on unified development subordinates the minuscule concerns of the lot by lot approach and brings forward larger questions. The identification of the planned unit for immediate development is one major question. Another is the assurance of its completion as a unit within a reasonable time.

The planned unit for immediate development should be of such a size, composition and arrangement that its construction, marketing, and operation is feasible as a complete unit without dependence on any subsequent unit or section. The common properties, the individual properties, and all other facets of the planned unit should be designed to achieve a unified environmental scheme with all elements in their appropriate locations and suitably related to each other, the site and the surrounding land.

There is no specific limitation on the maximum size of a planned unit and its homes association. Usually, however, it should not exceed about a thousand living units. The many advantages of having the common areas owned and maintained by a homes association di-

9 Urban Land Institute, The Homes Association Handboox (Tech. Bull 50, 1964). 
rectly responsive to its membership, as compared to public ownership, are apt to be lost when an association greatly exceeds this number. An extremely large association is likely to take on the aspect of a cumbersome and unresponsive bureaucratic organization. Associations of a few hundred living units, moreover, are large enough to support most common facilities, but not so large as to bring problems of communication and association vitality.

There are also practical limitations to the minimum size of a planned unit, depending upon such factors as the nature of the common areas and facilities, the costs of creating and maintaining them, and the income level, talents, and interests of the prospective association members. Relying on volunteer work to do large continuing maintenance is seldom realistic. Due to limiting factors, such as minimum facilities and organizational realities, a planned unit of less than fifty living units may not be practical except at relatively high costs per family.

\section{Time Stages in a Planned Unit Development}

To test a market or to size operations to his capacity, a developer may start with a relatively small planned unit. The original planned unit need only be large enough to be a complete and independent unit. This means it must be feasible to market the homesites and to operate the common facilities of the homes association successfully, even if no other land development is added to it.

By careful advance programming and planning, the developer later can develop additional adjoining lands and have them annexed to the original planned unit. To facilitate this, special legal provisions are needed. The developer must also give all homebuyers appropriate sales information about the immediate planned unit and the possible but unassured future annexations.

The common areas and facilities for each development stage should be planned so that each home owner, whether in the original planned unit or in an annexed area, will have an approximately equal financial stake in the homes association's facilities and about equal benefit from them. One approach for doing this is shown in the illustration of a three stage development in Figure 5.

In contrast to the expansion of a single planned unit, a single developer may build several separately operated planned units, each undertaken successively and without dependence on any other. The physical plan and legal foundations of such units should permit them voluntarily to federate with one another for matters of mutual concern or even to merge into a single consolidated homes association for the 
entire development. For example, a federation of the homes associations of several separate planned unit developments may do contract work for the individual associations and employ a full time manager, a bookkeeper, and maintenance personnel for the combined use of all the associations.

\section{The Scope of Land Use Intensity Standards}

The planned unit development concept challenges public authorities to use planning standards which are both meaningful and flexiblemeaningful in prescribing essential qualities, yet flexible in reserving to the developer and his planner the freedom to design imaginatively and effectively. In an effort to accomplish these objectives the FHA introduced a new approach, called Land Use Intensity (LUI), in a 1963 revision of its planning standards. ${ }^{10}$

A comprehensive concept of LUI is one feature of these standards. LUI expresses a group of six physical relationships in a developed property. First, it expresses the overall relationship of the amount of building mass (total floor area) to the amount of land area. Second, it relates total open space of a property to its total floor area. In other words it contrasts the exterior open space with the interior residential space, thereby relating the individual to his environment. Third, in considering exterior open space, LUI distinguishes between space that is for people, called livability space, and the space that is used for cars. Fourth, it considers large recreation space as well as other outside livability space. The final two ratios relate the number of car storage spaces to the number of living units. One considers only long term parking spaces for occupants, while the other considers all spaces including short time spaces for guests.

These six basic relationships are expressed as numerical ratios. Since the six ratios are related to one another in an orderly way, it is possible to express all six of them by a single number on a simple measuring scale of LUI. This simple measuring scale is another major feature of the new approach to planning standards. It is called the LUI scale.

In essence the new standards consist of the simple LUI scale coupled to a system of comprehensive information about important physical characteristics found in well planned residential properties. Correctly used, the standards will establish essential physical characteristics of a project, yet allow great flexibility in project design.

10 FHA, Minjumum Property Standards for Multifamity Housing No. 2600 (1963) (land use intensity standards are found in Chapter 3 and Appendix C); FHA, LAND-Use INTENSITY (Iand Planning Bull. No. 7 temporary ed. 1965) (scheduled for regular edition in 1966). 
The IUI concept and scale replace density, coverage and other less comprehensive and less meaningful measurement methods used in FHA's old standards. As we will see later, LUI has interesting possibilities as a replacement for such methods in local zoning.

\section{How the LUI Ratio Chart Works}

The key to the whole LUI story is the graph or ratio chart in Figure 6, which has been termed by House and Home "the clearest, most concise presentation of land-use regulations ever devised." 11 At a glance, it tells a developer or builder the maximum floor area he can build on a site and the minimum he can devote to recreation and other outdoor livability space. It works on the basis of the ratios explained by the marginal notes on the right of the graph in Figure 6.

For example, Builder $\mathrm{X}$ applies for an FHA insured mortgage on a garden apartment or town house project. FHA studies the site considering location, community, timing, the site's physical features and the housing market, then assigns an LUI number of 4.6.

This is all Builder $X$ needs to know. From here on he uses the graph. From the position of 4.6 on the bottom scale on the chart he notes that this is about twelve living units per gross acre depending upon living unit size and other design factors. From 4.6 on the bottom scale he reads up the vertical line above it. Each point where the line crosses a heavy curve line gives a numerical ratio on the vertical scale at the left of the graph. These ratios tell him his site planning limitations. Specifically:

Builder $\mathrm{X}$ finds his maximum floor area ratio is 0.3 , meaning that he may build no more than 0.3 square feet of floor area for each square foot of land area. Floor area is all indoor area except garages, boiler rooms, commercial space and common use rooms like recreation rooms. Land area is all land within property lines, plus half of abutting streets. Up to certain limits, half of any abutting public park or other open space is included if it will be beneficial to the project and permanently open.

As the drawing at the right of the chart shows, the permitted floor area may be built in one or more of a variety of building types. But the bars at the top of the graph suggest to Builder $X$ that the best building types at IUI 4.6 are two story townhouses and two story garden apartments. He may choose these or, if he prefers, other types which best fit the market and site conditions. This approach, which is illustrated in Figure 7 is in sharp contrast to the present monotony of a single building type used repetitively, and allows varied

11 House \& Home, FHA's New MPS: Big Step to Good Apartments, House \& Home Dec. 1963, p. 130. 
building types in an area while maintaining a constant intensity of land use.

Reading down the 4.6 vertical line to the curve for Open Space Ratio, Builder X sees he must make available 2.4 square feet of open space for each square foot of floor area. Open space includes all uncovered outdoor area, such as streets, parking, lawn, patios, recreation, as well as usable roofs and uncovered balconies. Half of roofed porches, carports and other covered open area is also counted as open space. The credit for these open spaces encourages the builder on a high intensity site to use improved roofs, underground garages and other methods of increasing open space.

The Livability Space Ratio curve at LUI 4.6 tells Builder X that for each square foot of floor area he must provide at least 1.5 square feet of outdoor area for people, that is areas other than for roads and car parking. Part of this Livability Space must be in moderately large areas called recreation space. The Recreation Space Ratio curve near the bottom of the graph shows Builder X he must provide at least 0.15 square foot of recreation area for each square foot of floor area. The area may be landscaped for quiet use or improved for active recreation.

Noting where the vertical line for LUI 4.6 crosses the Total Car Ratio curve, Builder $\mathrm{X}$ finds that he must provide at least 1.4 parking spaces for each living unit he builds. This includes short term parking for visitors and tradesmen. The next lower curve, the Occupancy Car Ratio curve, tells him that 1.2 car spaces per unit must have no limits on parking time so the homeowners or tenants will have around the clock parking. Like the other ratios, these are minimum standards, and Builder X may decide to exceed them in order to meet the market or other local conditions.

\section{Useful Characteristics of LUI}

The comprehensive scope of physical relationships embraced by LUI makes the FHA-LUI standards and scale very meaningful. Being precise and sensitive, moreover, the LUI scale is a responsive measure when used with understanding and skill. A minor change on the scale reflects a major change in physical relationships. For example, each unit of the LUI scale, such as from LUI 3.0 to LUI 4.0, doubles the floor area, or the density at a fixed dwelling size. The LUI scale is firmly based on a straight line projection of floor area ratio; see Figure 6.

The firm base of the LUI scale is in great contrast to older planning measurement methods, such as density. Wide variation in the size of living units and in number of occupants per unit make 
density a rather crude measure of the degree of land use. The variability of density when plotted against the firm LUI scale is shown in Figure 8. A vertical line at any point on this graph converts the LUI number to the number of living units per acre for various unit sizes. The chart shows the conversion to living units per gross acre, per net acre with twenty percent of the total area in streets, and per net acre with twenty-five percent in streets.

The meaning and sensitivity of the LUI curves in Figure 6 are matched by their reliability. They were derived scientifically from the computed ratios of scores of actual projects. At any selected point on the LUI scale a vertical line will identify a compatible set of ratios which determine readily attainable amounts of open space and car storage at the indicated floor area ratio. IUI also affords the predictability which permits the projection of an LUI number into physical and financial analyses of a proposed project prior to any project design work. This is easily done through a little arithmetic following a logical procedure outlined on a form mentioned below.

Obviously, determination of the appropriate LUI number for the site is crucial. Given the proper LUI number, the appropriate set of project ratios is quickly found on the standards graph in Figure 6. Applied to the known land area, the ratios directly produce the amounts for the actual physical components of a suitable project. The LUI system encourages good design and helps prevent bad planning. The pre-determined quantities save the designer from false starts with inappropriate sets of components, but do not of themselves assure the creation of a good design. This is the irreplaceable contribution of the designer working within the context of suitable physical components and the market requirements.

To demonstrate the compatability of the LUI system with good design, three housing projects of highly reputed design in the Southwest Renewal Area in Washington, D. C. are plotted in Figure 9 on the graph of the standard LUI ratios. The projects were designed prior to the development of the LUI system and were not in the data used in developing the system. Therefore the intensity ratios of these actual projects are entirely free of any influence on or from the standard ratios. Nevertheless the actual ratio curves of these outstanding projects fit neatly to the standard ratio curves with ample tolerance above the minimums.

\section{How FHA Uses LUI on a Proposed Project}

FHA uses the IUI system to analyze proposed multi-family housing projects and proposed planned unit developments. The FHA 
insuring office measures the LUI of successful existing projects to establish benchmarks on the LUI scale for comparative purposes. Then in considering a proposed site, it selects an LUI number based on planning analysis and sound real estate judgment regarding the proposed site, its community and the market. The LUI number establishes the intensity standards for the site for FHA's mortgage insurance purposes.

When selecting the LUI number, the FHA tests the physical and financial workability of the number or of the contemplated building type if either is in question. The physical test is done through planning judgment and the arithmetic illustrated on the technical worksheet in Figure 10. The financial test is by cost estimation and appraisal analysis based on the project components found in the physical test. ${ }^{12}$

The developer's planner, in turn and by the same process, may test various building programs for a site before starting to design the project. The pre-tested program guides the project planner by saving design time. In the design stage, the developer's planner and the FHA measure the LUI of a proposed plan to determine its compliance with the LUI number and standards assigned by the FHA.

Three worksheet forms are used in applying the LUI scale and standards to a proposed project. ${ }^{13}$ One provides a logical procedure for finding the LUI number of a site for FHA purposes. Another, mentioned above and illustrated in Figure 10, is used to extend an LUI number into a project program showing possible physical components of a proposed project. The third is used to measure the LUI of a proposed project design; see Figure 11. In addition to use by FHA, the latter two forms are timesaving technical worksheets available to interested developers for their optional use.

\section{FHA's LUI Number as Related to Local Zoning of a Site}

Recognizing the crucial nature of the LUI number assigned to a proposed site, FHA selects the LUI number for a site with utmost care through a comprehensive analysis outlined in the worksheet instructions referred to above. ${ }^{14}$ The LUI number selected by FHA represents the maximum intensity acceptable for site development with FHA-insured financing. Of course the development must meet other

12 FHA, How to Test the Financial Soundness of Rental Housing PropERTIES FORM No. 2484 (1951).

13 FHA, Instructrons For LAND-USE INTENSITX FORMs (1965) (scheduled for inclusion in the regular edition of Land Planning Bulletin 7, cited note 10, supra).

14 See note 13 supra. 
applicable standards, including compliance with the regulations of local public authorities.

The density requirement which applies to a site under local zoning is convertible to an approximation of an LUI number through the graph in Figure 8. Any such density requirement and its LUI equivalent represent the maximum intensity permitted by local zoning; lower intensity, of course, is always permitted. The site's LUI number for FHA mortgage insurance purposes may be based on different considerations than those affecting zoning and, therefore, may be lower than the equivalent of the zoning maximum. However, as a matter of policy, the FHA coordinates its activities with those of the local regulative authorities as much as possible and supports local planning and zoning based on sound principles. ${ }^{15}$ Accordingly, FHA does not knowingly assign a higher LUI number than the equivalent of the applicable local zoning maximum for the site. An exception to this policy exists when there is a proposal for a planned unit development.

Many zoning ordinances do not yet have provisions for routine local processing of planned unit developments. Because of this, FHA representatives may confer with local authorities at the earliest stage of a planned unit development in order to explain: (1) FHA's encouragement of the general concept of planned unit development presented in Bulletin 6; (2) FHA's desire to avoid involvement in local controversy about zoning of a specific site; (3) FHA's desire to avoid misunderstanding regarding the timesaving purpose of FHA's simultaneous processing of a planned unit development while others are working on the zoning; and (4) desirability for local authority to amend its zoning ordinance to include a general provision for routine processing of a planned unit development.

FHA coordinates its planned unit development processing with the activities of the local authorities to avoid misunderstandings and controversy. For example, FHA may release its LUI number even though it is higher than the applicable zoning equivalent if the local authority is considering a regulatory change and does not object to the release of the FHA number in advance of its decision on the matter. However, only if and when the development proposal is permissible under the then applicable zoning does the FHA issue a Subdivision Report firmly outlining its insurance requirements and inviting the builder to apply for FHA insured financing on proposed individual home properties in the planned unit development.

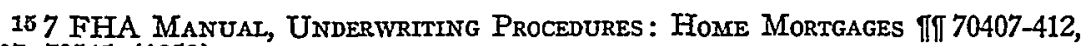
70507,70545 (1959). 


\section{LUI as a Tool in Local Planning and Zoning}

When the LUI concept was first presented, Max Wehrly, Executive Director of the Urban Land Institute, remarked:

We are inclined to feel that the concept . . . has a rather direct application in public land use regulations. We might even suggest . . . that the present methods of classifying zoning districts are obsolete and that a more productive and effective approach would be the use of some form of Land Use Intensity Districts. Revolutionary? So was zoning in 1916. In the intervening years we seem to have befogged rather than perfected the rather simple concepts originally associated with public land use regulations.

We offer this thought to the municipal official for his consideration. $^{16}$

Since then, LUI has been tested in use and adjustments have been made in an effort to perfect the standards and instructions. ${ }^{17}$ Although the relatively complex concept of six ratios may initially evoke a concern for workability, this disappears as the user gains familiarity with the simple LUI scale and finds through experience that the system works.

Aside from the FHA purpose for which the system was devised, LUI has characteristics which make it useful in comprehensive community planning for land use, transportation and other common facilities. It is also worth noting that LUI is especially adaptable to electronic data processing. While such master planning possibilities have not yet been explored, the LUI system has been used in local zoning. For example, Frederick County, Maryland incorporated it in its zoning ordinance in October, 1964. LUI is part of the standards for approval of a planned unit development as a conditional land use in any residential district. ${ }^{18}$ The zoning amendment incorporates LUI by reference to the FHA's standards, and except for the agricultural zone, establishes an LUI number for each zoning district. In the agricultural district the planning board determines the LUI number individually for each planned unit development application. ${ }^{19}$ The planning board rules on proposals for planned unit developments on the basis of the standards in the ordinance without the delay and

16 Editorial comment, Urban Land, Oct. 1963, p. 2.

17 See authorities cited notes 10,13 supra.

18 This planned unit development-LUI zoning amendment is reproduced in the appendix of this article.

19 This approach is in accordance with provisions in FHA Bulletin 7 on Land Use Intensity. See notes 10, 13 supra. 
complication of a public hearing. This approach has proved stimulating to developers and several proposals for planned unit developments are currently being prepared for application to the board.

In Norfolk, Virginia, a May 1965 interim zoning amendment permitting planned unit developments employs LUI standards comparable to the FHA system. For expediency, a single LUI level is used, but Norfolk is developing a comprehensive planned unit development amendment with the guidance of planning consultant Fred $\mathrm{H}$. Bair, Jr. The proposal includes an LUI contour map of the city. This determines the maximum intensity of a planned unit development at any location. The minimum size of a planned unit development varies with LUI, from ten acres at LUI 3.5, to one acre at LUI 6.5. Bair is advising Fairfax County, Virginia, in a similar approach. After a detailed study of LUI ${ }^{20}$ and these experiences in using it in zoning amendments, Bair concludes:

The Federal Housing Administration has made possible a major breakthrough in regulatory techniques. . . .

Use of the FHA approach, adapted to local circumstances, is strongly recommended for two reasons. First, the standards, based on extensive experience, are excellently drafted and organized, and provide a wide enough range so that they can be used in almost any situation. Second, since a very substantial amount of new development will be financed with FHA insurance on mortgages, use of the standards will reduce the complications which arise when several sets of regulations, all for approximately the same purpose are slightly at variance with each other. ${ }^{21}$

The zoning amendments discussed above still permit the builder to use the standard lot by lot development. The critical remaining question is: How does the local planning agency get the developer to leave the beaten path of routine lot by lot development in order to adventure on the higher road to better environmental design through planned unit development?

The intensity levels for planned unit developments in a zoning amendment may be equated closely with the local lot by lot standards. However, a somewhat higher intensity level is advisable to reach desired objectives. The planned unit development requires extra time and expense by the developer for design, legal documents, plan ap-

20 Bair, Development Policies for Metropolitan Suburbia, in Flordda Planning and Development 15-16 (1964-1965).

21 Bair, How To Regulate Planned-Unit Development for Housing-A Sumnary of a Regulatory Approach, 17 ZoNING Digest 185, 221 (American Society of Planning Officials 1965). 
proval, construction supervision, common area improvements and merchandizing. Because land is used more efficiently in a planned unit development, equal environmental quality can be produced with a somewhat greater number of dwelling units per gross acre. Without sacrificing quality, therefore, the costs of the developer's extra effort in a planned unit development can be offset by a savings through somewhat higher intensity of land use. An LUI bonus of at least fifteen percent seems warranted and desirable to make the planned unit development alternative more attractive to the developer than the routine lot by lot method.

\section{Making the Best Use of Our Land}

President Johnson in his message to Congress earlier this year said :

In the remainder of the century-in less than forty yearsurban population will double, city land will double, and we will have to build in our cities as much as all that we have built since the first colonist arrived on these shores. It is as if we had forty years to rebuild the entire urban United States. ${ }^{22}$

This means that about ten million additional acres of land will be urbanized by the year 2000. The carpeting of millions of acres with new homes need not thwart our efforts to provide open areas and a stimulating environment for an urban society. If planned unit development and LUI standards were to result in the dedication of open space equivalent to only five percent of the total new residential areas, half a million acres of parks and other urban open space would be created. Planned unit development and LUI could make this possible without extra initial costs to developers, home buyers or government, and, without an increase in the general tax burden.

22 Message on Cities-Message from the President of the United States, 111 CONG. REC. 3812 (daily ed. March 2, 1965). 


\section{APPENDIX}

Amendment of Zoning Ordinance of Frederick County, Maryland on Planned Unit Development and Land Use Intensity. Adopted October 1964.

Section 40-1. Definitions

Home Association. An incorporated, nonprofit organization operating under recorded land agreements through which, (A) each lot and/or home owner in a planned unit or other described land area is automatically a member and (B) each lot is automatically subject to a charge for a proportionate share of the expenses for the organization's activities, such as maintaining a common property, and (C) the charge if unpaid becomes a lien against the property.

Section 40-23. Planned Unit Development

(a) Purpose: The purpose of this section is to permit such flexibility and provide performance criteria which can result in planned developments which produce:

1. A maximum choice in the types of environment and living units available to the public.

2. Open space and recreation areas.

3. A pattern of development which preserves trees, outstanding natural topography and geologic features and prevents soil erosion.

4. A creative approach to the use of land and related physical development.

5. An efficient use of land resulting in smaller networks of utilities and streets and thereby lower housing costs.

6. An environment of stable character in harmony with surrounding development.

7. A more desirable environment than would be possible through the strict application of other sections of the ordinance.

The Planned Unit Development section is designed to provide for small and large scale developments incorporating a single type or a variety of residential and related uses which are planned and developed as a unit. Such development may consist of individual lots or it may have common building sites. Common land must be an essential and major element of the plan which is related to and effects the long-term value of the homes and other development. 
A planned-unit shall be a separate entity with a distinct character in harmony with surrounding development. In a Planned Unit Development there shall be no maximum building height, no minimum lot, no minimum lot width. However, no single family dwelling (except in a town house or semi-detached dwelling), and no addition to any single family dwelling shall be erected within a distance of less than sixteen (16) feet from any other single family dwelling.

(b) Location: The Planned Unit Development may be established in the R-1, R-2 or R-3 Residence Districts as authorized in subsection (h) of Section 40-72 and Sections 40-78 and 40-84. If the proposed project is in an A-1 district the desired residential rezoning shall be requested after the location and plans for the project have been approved by the Planning Commission. The criteria used in evaluating the appropriateness of a Planned Unit Development in an A-1 District shall be the same as that required for rezoning plus guide lines spelled out or indicated in other parts of the Comprehensive Development Plans. A zoning certificate for any structure in a planned unit development shall be issued only after the plans for such development have been approved by the Planning Commission. All structures in a planned unit development shall be constructed as shown on the approved plans.

(c) Submission of Plans: The developer shall present plans, reports and related information in sufficient detail to enable the Planning Commission to evaluate the proposed development in accordance with the provisions of this section. Any applicable standards of design and construction and procedure for submission of plans that may be adopted relating to subdivisions shall be followed.

(d) Plan Review: The Planning Commission shall investigate and ascertain that the plans for a Planned Unit Development meet the following conditions:

1. That the tract of land for the project comprises not less than ten (10) acres. It may be owned, leased or controlled either by a single person, or corporation or by a group of individuals or corporations.

2. That the standards for maximum floor space permitted and for minimum recreation space, outdoor living space, open space and parking space requirements are related to a land use intensity rating (LUI). The relationship between ratings and standards are established by the Minimum Property Standards for Multi-family Housing (FHA 2600) dated November 
1963. The land use intensity rating for a planned-unit development shall relate to the zoning districts. The overall maximum rating for projects, (excluding commercial and industrial areas) permitted in each district is:

$\begin{array}{cc}\text { District } & \text { Rating (LUI) } \\ \text { R-1 } & 3.7 \\ \text { R-2 } & 4.5 \\ \text { R-3 } & 5.3\end{array}$

In the A-1 District the land use intensity rating for plannedunit development shall be determined by the Planning Commission. The Commission in determining the rating shall follow the procedure in FHA's Land Planning Bulletin No. 7, entitled Land use Intensity Rating; dated September 1963. The determination of the land use intensity rating in the A-1 District shall be completely documented including all facts, opinions and judgments justifying the selection of the rating.

3. That the buildings are to be used for residential purposes; except where:

a. the development contains 100 or more dwelling units, 2400 square feet of floor area for every 100 dwelling units may be for limited commercial use. This commercial area may be in a separate building or incorporated with a twofamily or a multi-family structure.

The following requirements shall be met before such commercial use may be incorporated:

(1) The structure if separate shall be of an architectural design compatible with that of the dwelling units.

(2) Any single commercial area shall be limited to 2400 square feet of floor area.

(3) One parking space for every 400 square feet of floor shall be provided.

(4) Signs shall be limited to an identification sign for each point of access. The signs shall not exceed two square feet in area, shall not be directly lighted and shall be attached flat against the face of the buildings or other architectural structure.

b. the development contains 500 or more dwelling units, one acre of land for every 100 dwelling units may be used for commercial purposes. Only uses permitted in the B-1 and 
B-2 districts may be included. Where the development contains 1,000 or more dwelling units five (5) acres of land for every 100 units may be used for light industry (uses permitted in the M-1 district). Individual industrial areas shall be a minimum of 50 acres. Customary, accessory or associated uses, such as private garages, storage spaces, recreational and community activities, churches and schools are also permitted.

4. That the proposed project will constitute an environment of sustained desirability and stability, that it will be in harmony with the character of the surrounding neighborhood.

5. That the project is in conformity with the policies and goals of the Comprehensive Development Plans, and will be consistent with the intent and purpose of this chapter.

6. That the property adjacent to the proposed development will not be adversely affected.

7. That every structure containing dwelling units have access to a public street directly or via a court, walkway or other area dedicated to public use or owned and maintained by a Homes Association, but need not front on a road as defined in Section 40-1 and Section 40-10.

8. That the elements of the plan, (houses, streets, parking areas, walks, service areas, plant material, open space, recreation areas and facilities, walk and screening, lighting, community buildings, and maintenance and storage facilities) are arranged and designed to reflect the principles and objectives outlined in sections 5 and 6 of the FHA's Land Planning Bulletin No. 6, entitled "Planned Unit Development with a Homes Association," dated December 1963.

(e) Utilities: The method for providing water and sewerage for the development must be approved by the Health Department before the Planning Commission approves the plans.

(f) Homes Association: A Homes Association will be required if other satisfactory arrangements have not been made for improving, operating and maintaining common facilities including streets, drives, service and parking areas and recreation areas. When required, the owner(s) must establish a Homes Association in accordance with the requirements and procedures outlined by FHA in Sections 7 and 8.2 of the Land Planning Bulletin No. 6, entitled, "Planned Unit Development with a Homes Association," dated December 1963. 
Figures 1 ThroUGH 11 


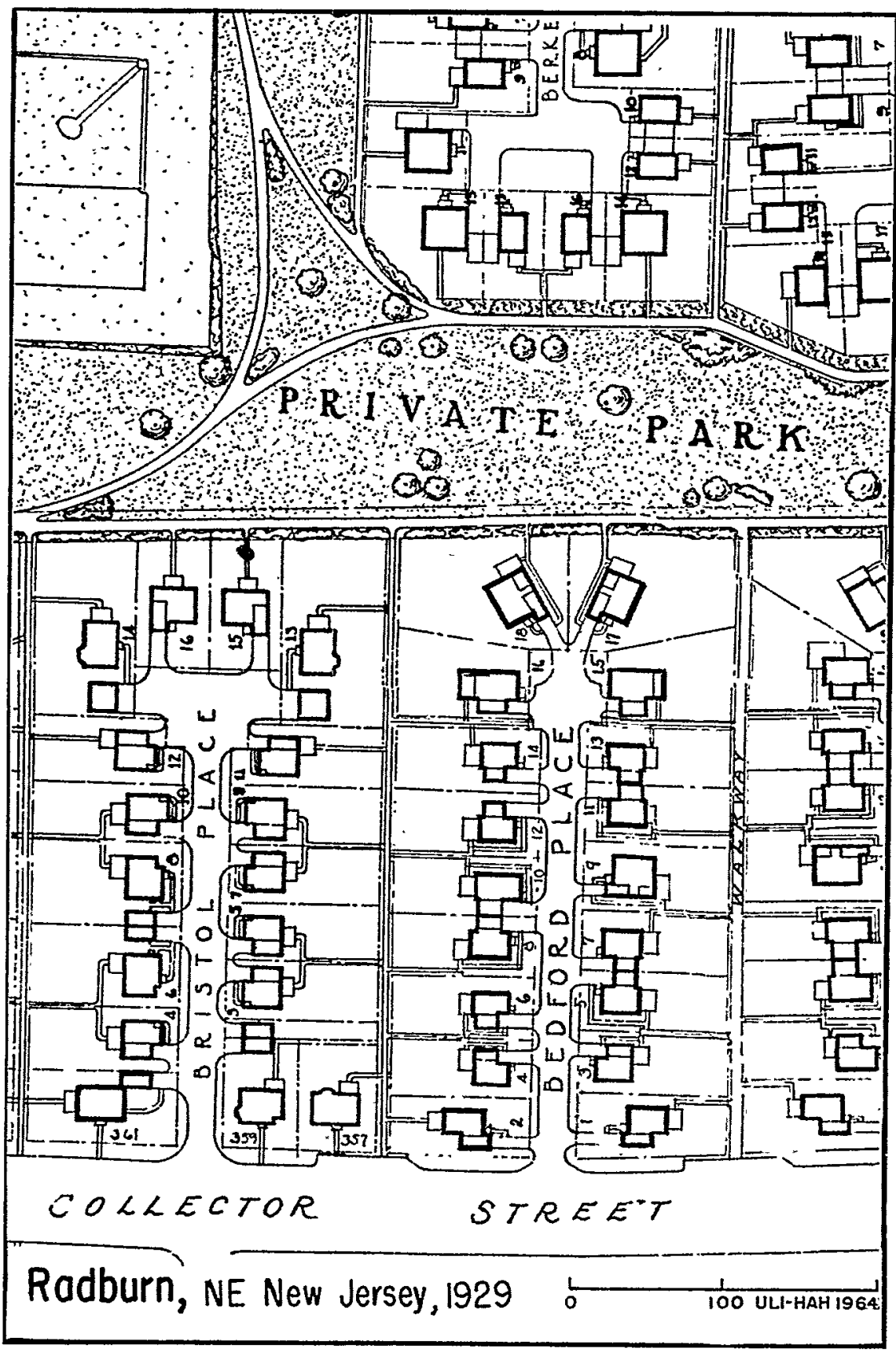

Figure 1. Portion of a Superblock at Radburn, Fair Lawn, New Jersey 


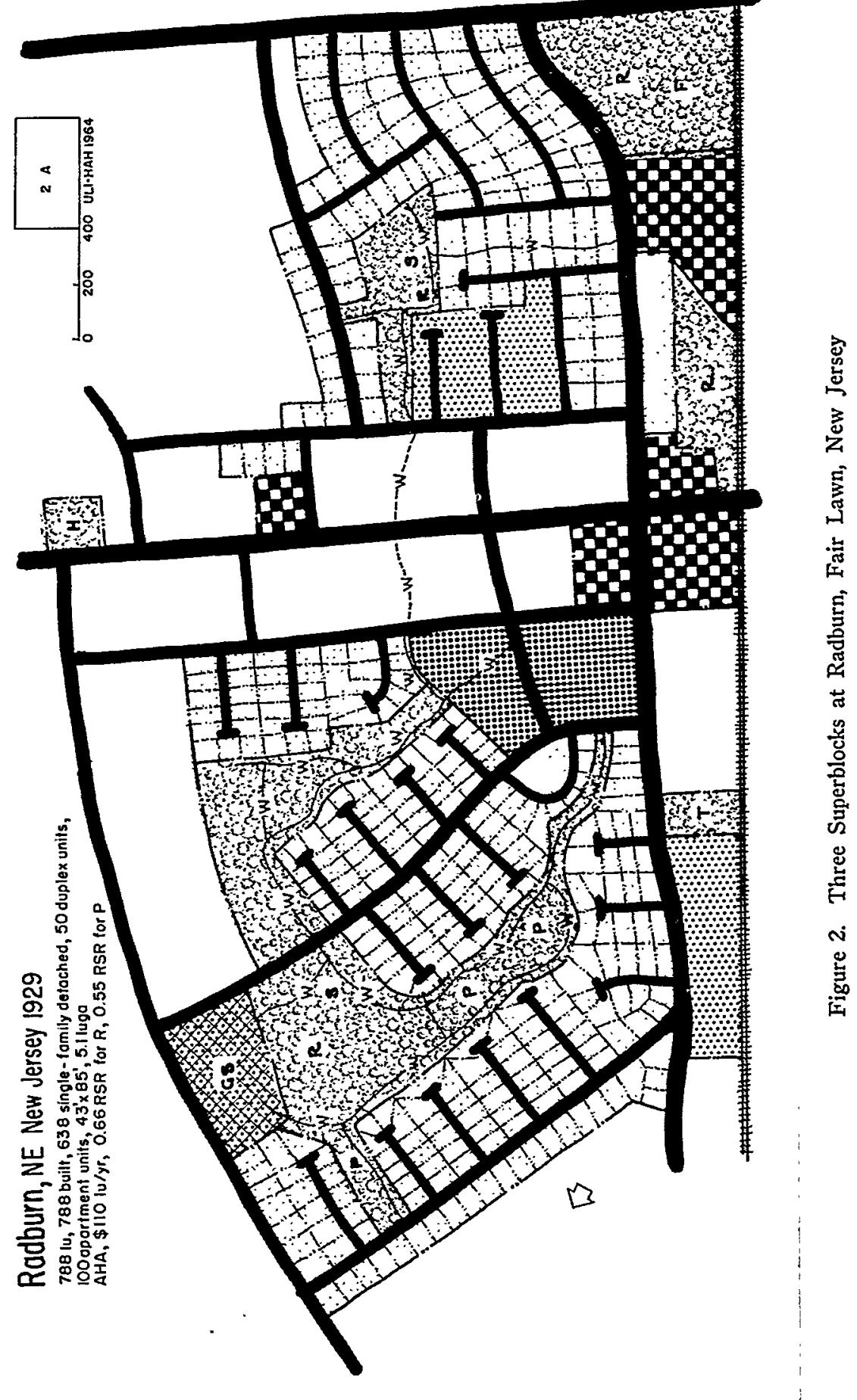




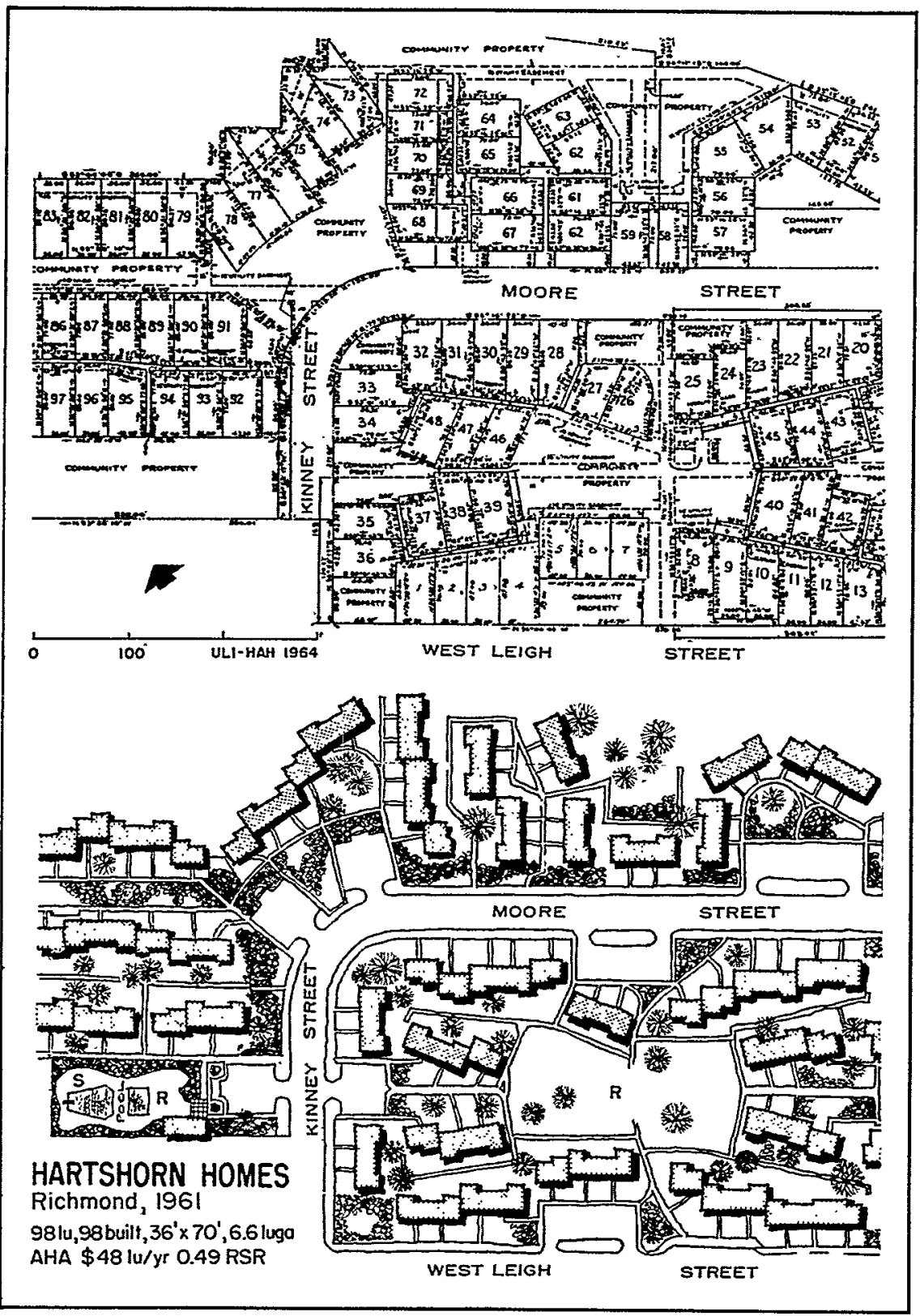

Figure 3. Recorded Plat and Site Plan. Hartshorn Homes, Richmond, Virginia (6.6 living units per gross acre) 


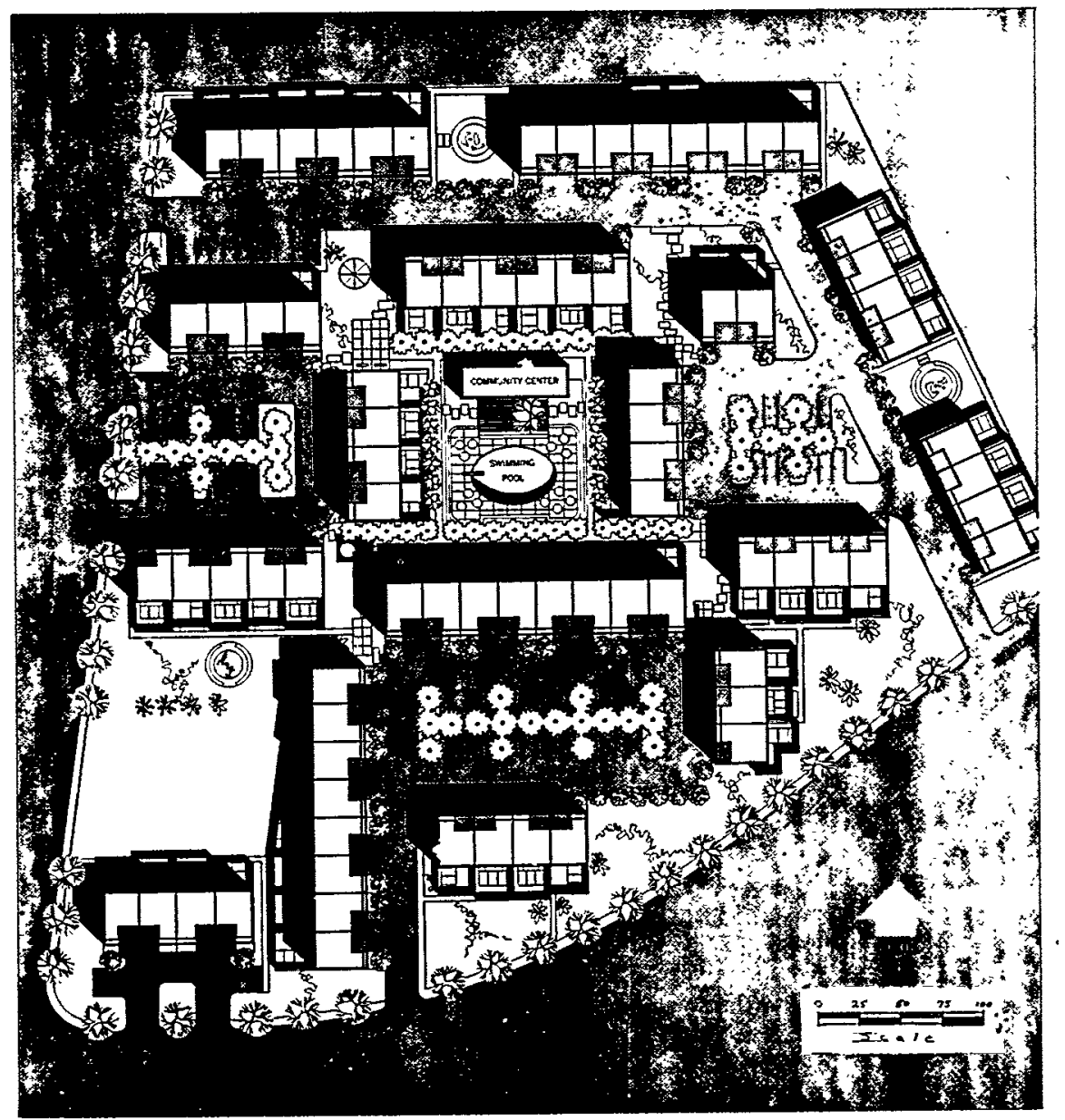

Figure 4. Site Plan. Pomeroy Green, Santa Clara, California (11.0 living units per gross acre) 


\section{STAGED DEVELOPMENT: A PLANNED UNIT STARTS SMALL--AND EXPANDS}

\section{STAGE 1 CREATES THIS . . .}

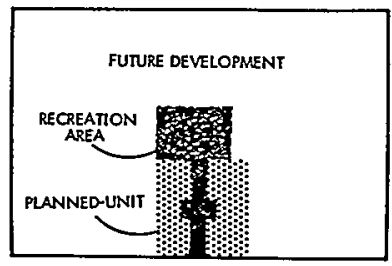

\section{STAGE 2 ADDS THIS ...}

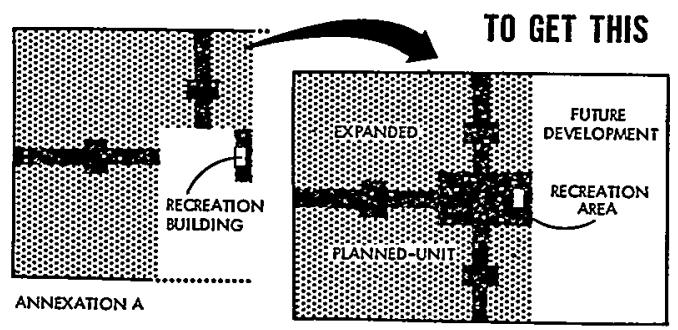

\section{STAGE 3 ADDS THIS . . .}

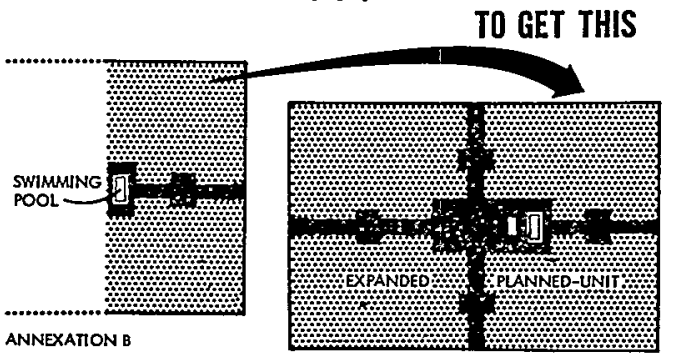

The developer first makes general advance programs and plans for a future development of several hundred homes. Then in Stage 1 he proceeds only with an original planned-unit of about fifty homesites. This includes a major open area for recreation with modest improvements such as landscape work and tennis courts. He defers expensive facilities like a swimming pool because of the small number of homesites at this stage. He controls the adjoining lands, but no firm decisions or assurances are made regarding their future development.

With the original planned-unit completed and its homes association in operation, the developer now starts on a large adjoining land area and constructs a major recreation building. The new land area is annexed to the original planned-unit in accordance with an advance agreement with its homes association. Through the annexation, the owners of all homesites in the new area automatically become members of the homes association, and the recreation building and its site are dedicated to the association.

The annexation of additional property at Stage 3 follows the same pattern established in Stage 2. At this stage, a swimming pool is added, together with its site. When Stage 3 has been completed, the small, original planned-unit has been transformed into a rela. tively large one with a variety of recreation facilities. In essence, the developer has programed, planned and completed the development on a basis of "pay-as-you go" rather than "go-for-broke." 


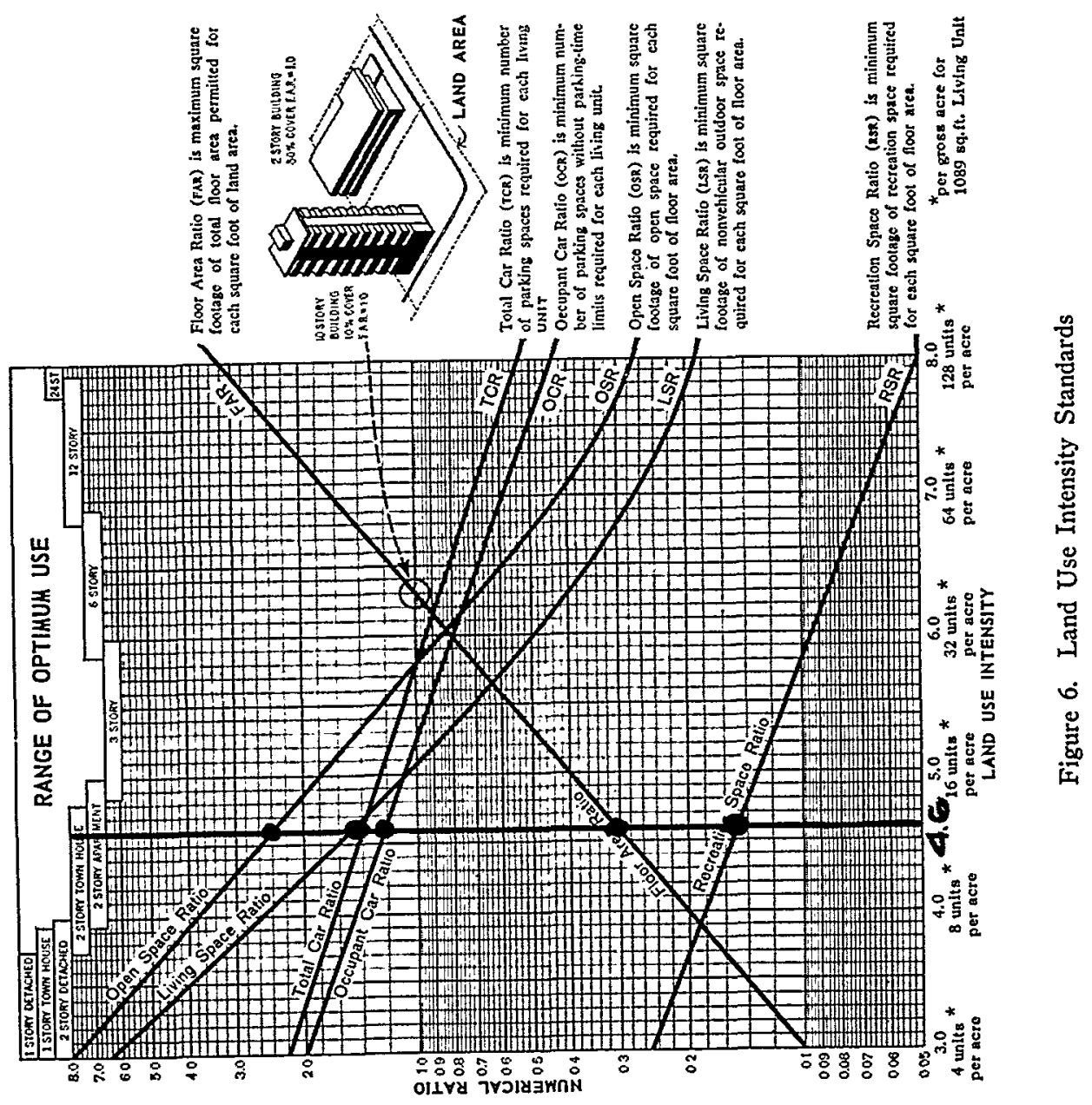




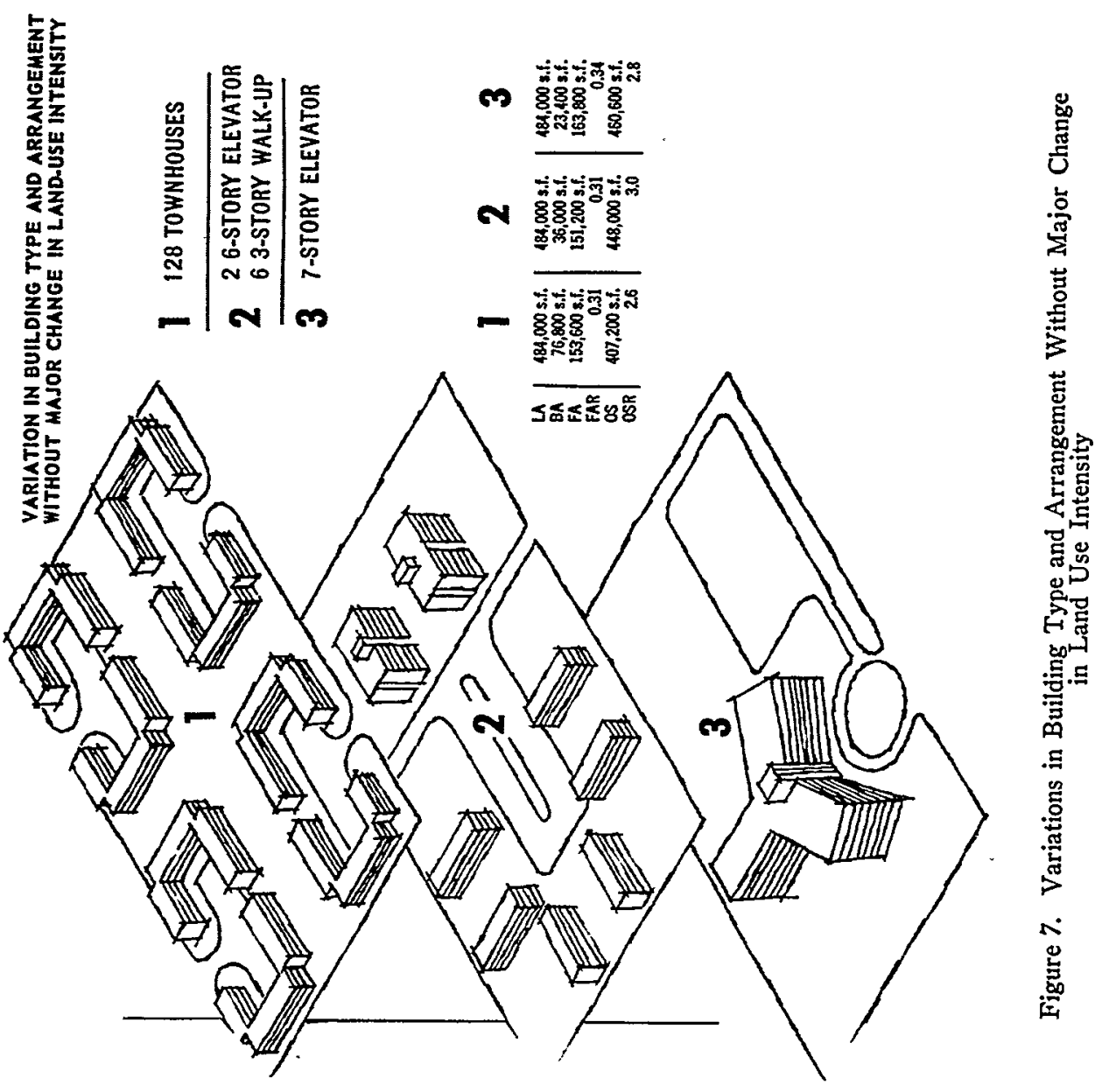



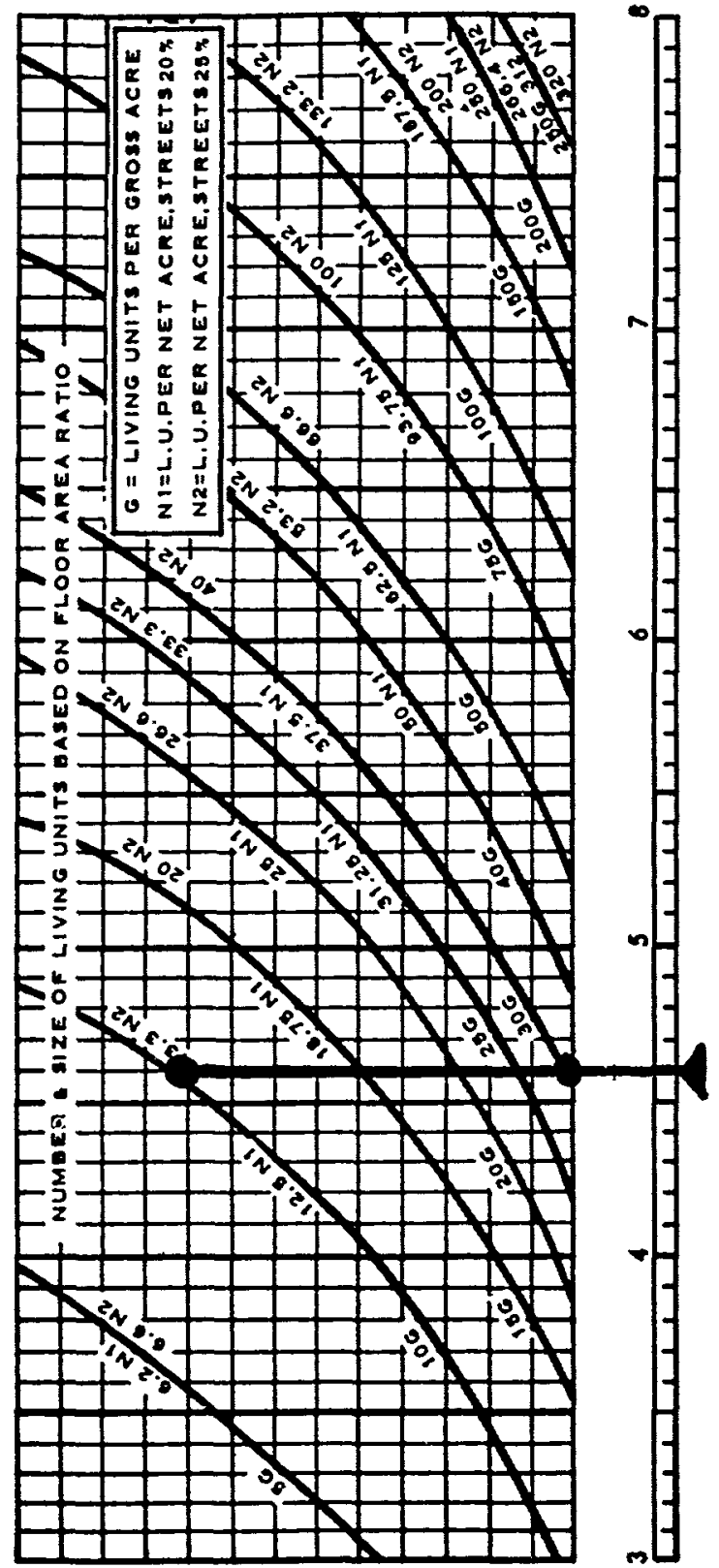

பั

告

峲

岂

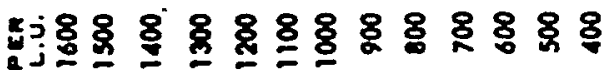




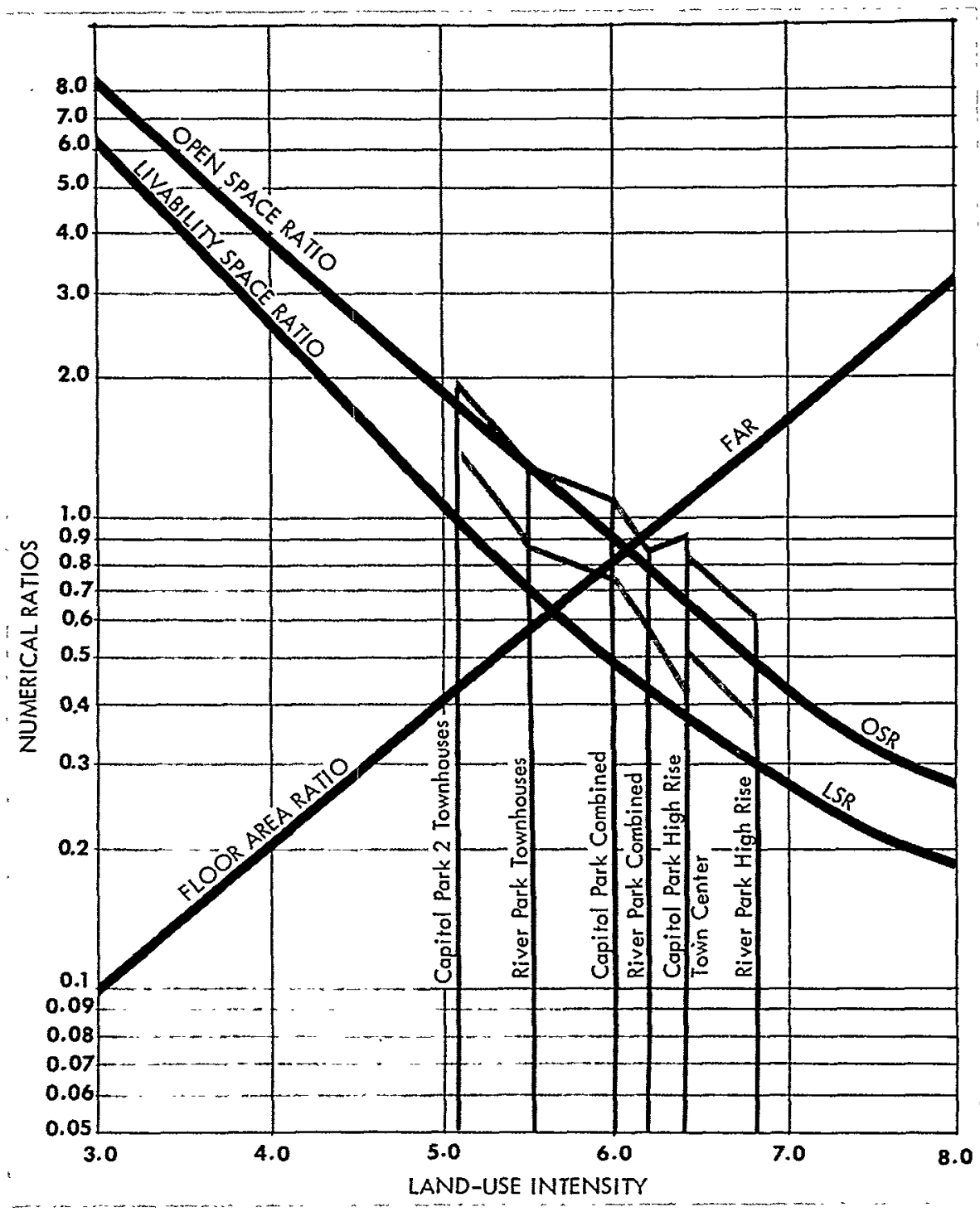

Figure 9. Open Space and Livability Ratios of Projects in Southwest Renewal Area of Washington, D. C. Compared with Standard LUI Ratios 
FHA FORM NO. 1028

PROJECT PLANNING PROGRAM

11/64

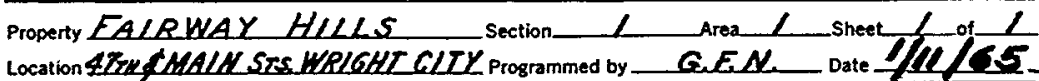

A UNO-USE IMTEMSITY FOR THE AREA: LUL 26

8. HLO-USE IMTEMSITY STAMDAROS 1. Maximum Floor Area Ratio

2. Minimum Ooen Space Ratio

3. Minimum Livability Space Ratio

4. Minimum Recreation Space Ratio

5. Minimum Occupant Car Ratio

6. Minimum Total Car Ratio

D. DEVELOPMENT OF PLAHING PROGRAM

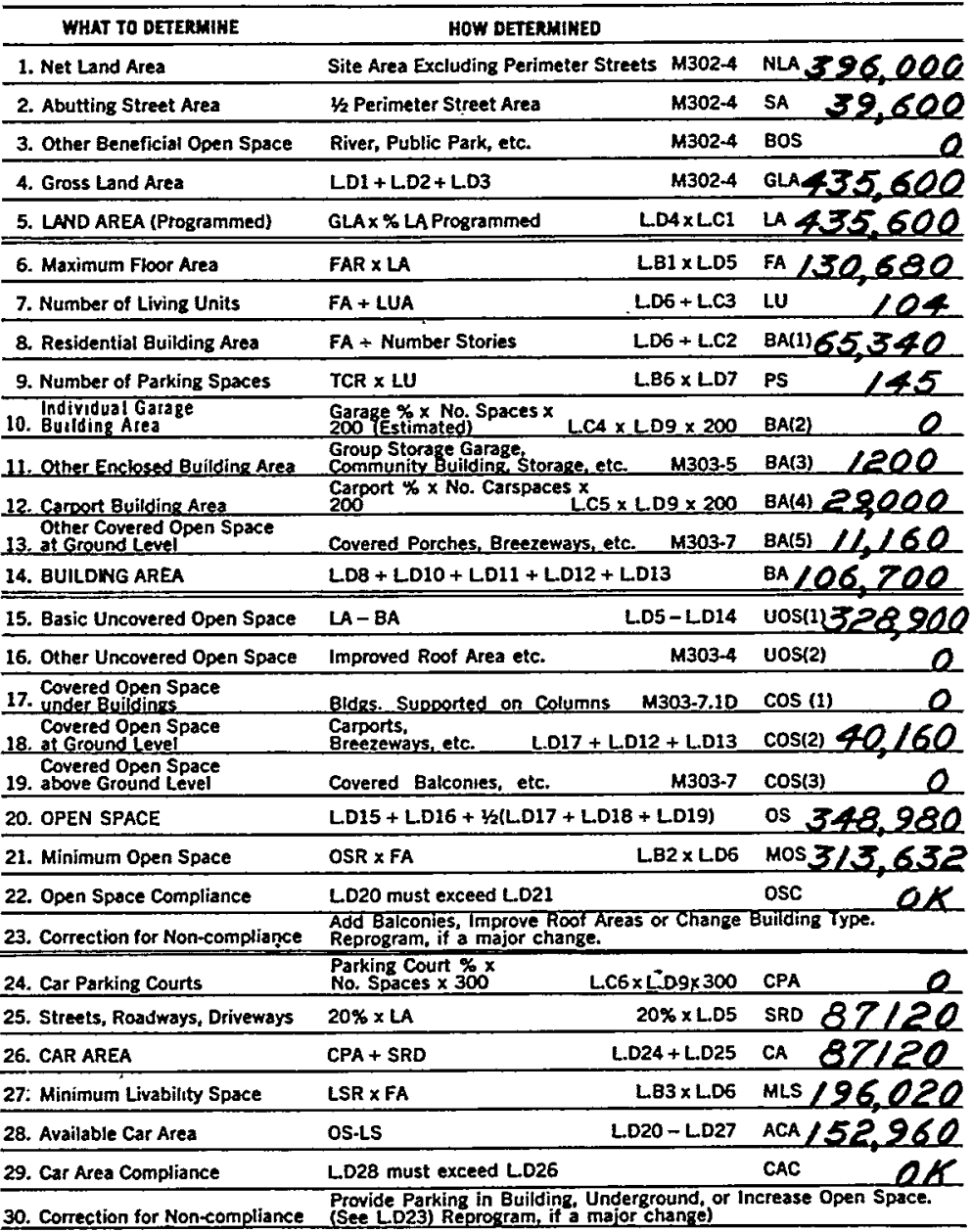

FORM MO. 1028

c. EASIC DATA FOR PROGRAM

1. \% of Land Area Proframmer

2. Buildine Type $2 s$

3. Adiusted Livin I Unit Are?

4. \% car Spaces in Garapes

$5 \%$ Car spaces in carports

$6 \%$ Car Spaces in Parking Counts

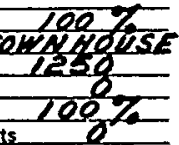


FHA FORM NO. 1029 LAND-USE INTENSITY OF A PROJECT PLAN

11964

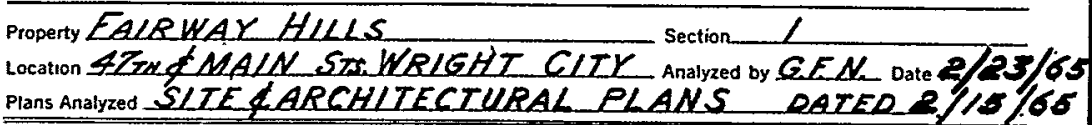

A. ASSIGNED AKD COMPUTEO LAMO-USE INTEHSITY

\begin{tabular}{|c|c|c|c|c|}
\hline \multirow[b]{2}{*}{ 1. Land-use Intensity (LUI)................. } & \multicolumn{2}{|c|}{ Assigned to the Site } & \multicolumn{2}{|c|}{ Computed for the Plan } \\
\hline & Assigned & LU1 & Computed & LUI \\
\hline 2. Floor Area Ratio (FAR) .................. & Maximum & FAR & Line 86 & FAR \\
\hline 3. Open Space Ratio (OSR) ................. & Minimum & OSR & Line $\mathrm{B18}$ & OSR \\
\hline 4. Livability Space Ratio (LSR) ............ & Minimum & LSR & Line B22 & LSR \\
\hline 5. Recreation Spacę Ratio (RSR) ....... & Minimum & RSR & Line B24 & RSR \\
\hline 6. Occupant Car Ratio (OCR)............... & Minimum & OCR & Line $\mathbf{B 2 8}$ & OCR \\
\hline 7. Total Car Ratio (TCR)....................... & Minimum & TCR & Line B30 & TCR \\
\hline
\end{tabular}

8. WHAT TO DETERHIME HOW DETERMIKED

DETERMIMATION

\begin{tabular}{|c|c|c|}
\hline 1. Net Land Area & Site Ares Excluding Perimeter Streets M302-4.1a & NLA 396,200 \\
\hline 2. Abuttuil Street Area & 1/2 Perimeter Street Area & ASA \\
\hline 3. Beneficial Open Space & River, Public Park, etc. & BOS \\
\hline 4. LAND AREA & Project LAND AREA & LAS \\
\hline 5. Floor Area & Floor Area on All Floors & $\mathrm{FA} / 28,750$ \\
\hline 6. FLOOR AREA RATIO & L.BS - L.B4 & FAR \\
\hline 7. Resldential Building Area & Residential Floor Area at Ground Level & $\mathrm{BA(1)} 64,370$ \\
\hline 8. Garage Building Area & Enclosed Car Parking Area & BA(2) \\
\hline 9. Other Enclosed Building Area & Community Building, Storage, etc. & BA(3) \\
\hline 10. Carport Building Area & Covered Car Parking, (Open Sides) & BA(4) \\
\hline $\begin{array}{l}\text { Other Building } \\
\text { 11. Area at Ground Level } \\
\text { 12. BUILDING AREA }\end{array}$ & $\begin{array}{l}\text { Covered Porches, Breezeways, etc. } \\
\text { Enclosed BA+COS } \\
(L .87+L . B B+L . B 9)+(L . B 1 O+L . B 11)\end{array}$ & 270 \\
\hline 13. Basic Uncovered Open Space & L.B4 - L.812 & vos(1), \\
\hline 14. Other Uncovered Open Space & Improved Roof Area, Open Balconies, etc. M303-6 & uos(2) \\
\hline $\begin{array}{l}\text { Coyered Open Space } \\
\text { 15. at Ground Level } \\
\text { Covered Open Space }\end{array}$ & $\begin{array}{l}\text { Open Space under Buildings on Piers. } \\
\text { Carports, Breezeways, etc. }\end{array}$ & $\cos (1)$ \\
\hline $\begin{array}{l}\text { Covered Open Space } \\
\text { 16. Above Ground Level }\end{array}$ & Covered Balconies, etc. & $\cos (2)$ \\
\hline 17. Open Space & $\mathrm{UOS}+1 / 2 \cos (\mathrm{L} . \mathrm{B} 13+\mathrm{L.B14})+1 / 2(\mathrm{~L} . \mathrm{B} 15+\mathrm{L} . \mathrm{B} 16)$ & os \\
\hline 18. OPEN SPACE RATIO & L.B17+ L.B5 & OSR \\
\hline 19. Car Movement Area & $\begin{array}{l}\text { 1/2 Roadways of Abutting Street. } \\
\text { On-site Roadwrays and Drives }\end{array}$ & 500 \\
\hline 20. Car Storage Area & 3/2 Carport Area + Parking Courts & $\operatorname{cs} A 2$ \\
\hline 21. Livability Space & L.B17 - (L.B19 + L.B20) & is 24 \\
\hline 22. LIVABILITY SPACE RATIO & L.B21 - L.B5 & 18 \\
\hline 23. Recreation Space & LS. Countable as RS & 500 \\
\hline 24. RECREATION SPACE RATIO & L.B23+L.85 & 0.16 \\
\hline 25. Number of Living Units & Count All Floors of All Buildings & 104 \\
\hline 26. Gross Density & L.B25 - L.B4 (in acres) & 10.4 \\
\hline 27. Number Occupant Car Spaces & No. Spaces (without time limit) & 124 \\
\hline 28. OCCUPANT CAR RATIO & L.827 $\div$ L.B25 & 1.2 \\
\hline 29. Number Guest Car Spaces & No. Spaces (time may be limited) & 50 \\
\hline 30. TOTAL CAR RATIO & $(L . B 27+L . B 29)-L . B 25$ & 1.62 \\
\hline
\end{tabular}

FORM NO. 1029

LAND.USE INTENSITY OF A PROJECT PLAN

Figure 11. Form Used to Compute the LUI of a Project Plan, either to Find the LUI of a Selected Benchmark Project or to Check the Compliance of a Proposed Plan with the Standards of the LUI Number Assigned to a Site 